\title{
Deconstrucción del discurso bélico en el Poema Heroico de Hernando Domínguez.
}

\section{War Discourse's Deconstruction in the Poema Heroico by Hernando Domínguez.}

\section{Resumen}

El propósito de este análisis es demostrar la manera en la cual el escritor neogranadino Hernando Domínguez Camargo deconstruye, a través de sus octavas, la visión bélica que exalta la Conquista española, por medio de un análisis meticuloso de algunos momentos de su obra magna: el Poema Heroico.

Palabras claves

Hernando Domínguez Camargo, Poema Heroico, discurso bélico, Conquista española, deconstrucción.

\begin{abstract}
The purpose of this analysis is to demonstrate the way in which the Neogranadian author Hernando Domínguez Camargo deconstructs, through the use of the ottava rima, the war vision which exalts the Spanish conquest, by means of a meticulous exam of some octaves of his great work: the Poema Heroico.
\end{abstract}

Keywords Hernando Domínguez Camargo, Poema Heroico, war discourse, Spanish Conquest, deconstruction. 
CATEDRAL TOMADA: Revista de crítica literaria latinoamericana / Journal of Latin American Literary Criticism Deconstrucción del discurso bélico en el Poema Heroico de Hernando Domínguez.

\section{Anotaciones preambulares sobre la obra y el autor}

Hernando Domínguez Camargo, poeta bogotano del siglo XVII (16061659), dejó una gran obra épico-lírica, a saber, su Poema Heroico dedicado al fundador de la Compañía de Jesús: San Ignacio de Loyola. Esta obra, inconclusa y póstumamente editada (1666), como lo fueron sus demás obras también $(1675)^{1}$, no empezó a recibir la atención de los críticos sino hasta el siglo pasado cuando Gerardo Diego hizo un reconocimiento de sus poemas resaltando sus sensuales cuadros poéticos de figuras humanas, escenarios lujosos y paisajísticos, con los cuales hace gala de su aptitud imitadora. (41)

Este estudio se centrará en el aspecto épico del poema hagiográfico, específicamente en la deconstrucción que opera en muchas de sus estrofas en lo que se refiere al discurso que exalta la empresa bélica de conquista española.

\section{Deconstrucción del discurso bélico imperialista en la obra magna domingueña.}

Dentro del exordio, el poeta expresa su deseo de un "Nuevo aliento que articule heroica fama" (39). La palabra en cursiva es una adición mía), verso que bien pudiera referirse a la originalidad a la que aspira el escritor por medio de dar un nuevo aliento, una voz nueva, un tipo de fama heroica, cincelada de manera muy particular. Esto significaría, al decir de Cros, que "un ya dicho, soporte a la significación, al mismo tiempo se deconstruye en ella, en todos los niveles" (101). El ya dicho, en este caso, sería el discurso épico, en muchos poemas de la época colonial, exaltador de hazañas de héroes en el plano militar, las hazañas de la Conquista (Hampe 121), si se piensa en obras españolas y coloniales; sobre ese ya dicho, Domínguez, a su manera, opera un tipo de deconstrucción.

\footnotetext{
${ }^{1}$ Se trata de 1675 y no de 1676 como lo han señalado algunos estudiosos, y según se encuentra en el catálogo de la Biblioteca Nacional de España.
} 
El yo poético ${ }^{2}$, a lo largo de todo el Poema..., destila una crítica aguda en contra de la guerra, no sólo por lo que ha implicado para América, sino para Europa y, por extensión, para el mundo entero. A continuación, presentaré un análisis de cómo el asunto épico es deconstruido en el Poema...

El "Libro primero" relata que desde pequeño Ignacio demuestra interés por lo bélico y recibe instrucción en este oficio en su ciudad natal. Allí pisa la "corte de césares hispanos". Esos césares hispanos, comparados en los altos mares a "coronados Caribdis soberanos" y la consecuente invectiva del poeta en contra de las vanidades y excesos, incluidos la ambición y la ostentación, desdicen de la escena bélica de Conquista, rebajándola al grado de saqueo. Para presentar ese grado de saqueo, el poeta, a través de una metáfora mitológica, compara a los césares hispanos con Caribdis. $\mathrm{Al}$ abrir este cuadro intertextual ${ }^{3}$ que lo remonta a la mitología griega, el lector se encuentra con un monstruo femenino, hija de la Tierra y Poseidón, que habitaba en tiempos antiguos en Mesina; siendo humana había mostrado su carácter superlativamente voraz. Una vez que por allí pasó Heracles conduciendo los rebaños de Geriones, Caribdis los devoró después de haberlos arrebatado, por lo cual recibió castigo de Zeus, quien la precipitó en el mar, en donde se convirtió en monstruo. Tres veces al día, Caribdis absorbía agua marina en grandes cantidades, devorando todo lo que flotaba, incluso los barcos que por allí pasaban (Grimal 86-87). Con este cuadro intertextual en mente, queda clara para el lector la intención del yo poemático de mostrar su visión negativa de lo que la Conquista española significó en términos de devoración de los productos americanos. Para mayor claridad, se anota la octava de interés: "Augusto así garzón, pisó los lares/ de la corte de césares hispanos,/ que de fortuna son en altos mares/ coronados Caribdis soberanos:/ donde en náufragos votos, los altares/ de

${ }^{2}$ El yo poético centra la experiencia lírica en el yo, aunque se puede hacer extensivo a un grupo del que el hablante forma parte, es decir, puede hacer alusión a la primera persona del plural para de ese modo reconocerse como alteridad (Segre 336).

${ }^{3}$ Los cuadros intertextuales "[...] son esquemas retóricos o narrativos que forman parte de un repertorio seleccionado y restringido de conocimientos que no todos los miembros de una cultura poseen" (Eco 120). El lector a menudo los extrae de su propia enciclopedia histórica, literaria, entre otras. 
CATEDRAL Tomada: Revista de crítica literaria latinoamericana / Journal of Latin American Literary Criticism Deconstrucción del discurso bélico en el Poema Heroico de Hernando Domínguez.

ídolos fatiga cortesanos/ indiana nao, que en preciosa suma,/ carga de oro por cargar de espuma" (Domínguez 60).

Los "césares hispanos", o lo que es lo mismo, el poder español, es asumido entonces como monstruo devorador a quien la Fortuna, la diosa de la Casualidad (Grimal 207) o de la suerte, buena o mala, permite coronarse en los altos mares y aunque en la octava el término fortuna no está en mayúscula para indicar un sustantivo propio, en la época de Domínguez parece tener el mismo sentido que se le da en este trabajo; la clave está dada por Covarrubias para quien esta palabra significa "vulgarmente lo que sucede a paso, sin poder ser prevenido [...]. Los gentiles la hizieron diosa" (605). De la anterior definición sincrónica, desemboca la visión de esta empresa bélica de Conquista puesta, no como empresa divina, no como hazaña humana, sino como mera casualidad; esta empresa es, consecuentemente, desheroizada por completo, además de mostrarse sus consecuencias. Aquí, el adverbio de lugar "donde" (verso cuarto), parece referirse a la corte española, cuyos altares son fatigados o cansados debido a la gran suma de oro cargada por la "indiana nao", por la nave procedente de las Nuevas Indias.

La crítica de la expoliación de América también se incluirá en el apóstrofe ${ }^{4}$ de Ignacio a las armas e indumentaria soldadesca que abandonará para dedicarse a su guerrear religioso; así, Ignacio se dirige a la espada, al pavés, a la celada, al peto y al espaldar que le han servido como medios de ataque y defensa (130, 131). La espada, por ejemplo, está ligada al honor sólo en algunas ocasiones, y se ha vinculado a la nave oceánica para ganar nuevos mundos de gloria con sangre ajena: “¡Oh espada, dijo, bien nacida, llave/ que las chapas abriste de la vida, [...]/ timón, que vinculándote a la nave/ de mi fortuna, en muchos conducida/ mares de ajena sangre, que inculcaste,/ nuevos mundos de gloria me ganaste!"' (130).

\footnotetext{
${ }^{4}$ Para la revisión y explicación de algunas figuras literarias y retóricas encontradas en los versos de este estudio, me he basado en la Introducción al estudio de la literatura (Brioschi y Girolamo) y el Diccionario de retórica, crítica y terminología literaria (Marchese y Forradellas).
} 
En ese mismo canto y después de la invectiva en contra de los vicios cortesanos, se describe de manera pictórica el entrenamiento que Ignacio recibe para la guerra. Esa descripción de ese adiestramiento sigue los patrones épicos que se remontan a Horacio, con lo que se quiere decir que la caza de animales como prefiguración del oficio bélico en el Poema... no es nueva en Hernando Domínguez. Lo nuevo en el poeta neogranadino vendría a ser la introducción del tópico natural en ese entrenamiento y la connotación que adquiere dentro del Poema... Después de hacerse la aclaración de que el santo no participa de los antivalores y la hipocresía reinante en la corte española, en donde recibe su entrenamiento como soldado al servicio del rey, se introduce una octava a través de la cual el poeta compone una agudeza compuesta ${ }^{5}$, agudeza que reúne otros tipos de agudezas. Los dos primeros versos cuentan que Ignacio se prepara para la guerra a través del ejercicio de la caza. Pero, más tarde, terminando el segundo verso, empieza con la ponderación de un misterio. Este tipo de agudeza "Consiste el artificio de esta especie de agudeza en levantar misterio entre la conexión de los extremos, o términos correlatos del sujeto, repito, causas, efectos, adjuntos, circunstancias, contingencias; y después de ponderada aquella contingencia y unión, dase una razón sutil, adecuada, que la satisfaga" (Gracián 37). La ponderación misteriosa en el poema se da en la presentación del halcón que ofrece sus plumas a los pinceles de Ignacio. En el quinto verso usa dos agudezas por semejanza (metáforas): con la primera se compara el venablo a un tiento. Entre las múltiples definiciones dadas por el diccionario de la RAE en línea para la palabra "tiento", se encuentra la siguiente, aplicada a la pintura: "Varita o bastoncillo que

\footnotetext{
${ }^{5}$ En la agudeza mixta o compuesta, agudeza ajustada al discurso, el juego no se limita a levantar diversos asuntos como si discurrieran libremente sin alguna relación; no, en lugar de eso, encadena en una traza los asuntos que se unen entre sí, componiendo un todo artificioso (Gracián 273), palabras más, palabras menos, teje en una sola red diversos tipos de agudeza en un mismo texto alrededor de un mismo asunto, lo cual hace aún más difícil para el lector actual la interpretación. Para Gracián, sin embargo, este tipo de agudeza es el ideal, pues cuanto más se dificulta la urdimbre de las conexiones, tanto más la dificultad de penetración en el sentido y, por ende, es mayor el valor del juego conceptuoso. Gracián menciona que se pueden dar diferentes tipos de agudeza sin conexión entre ellas y que le apuntan a diferentes elementos, no relacionados entre sí; para Gracián, entonces, el valor de la agudeza compuesta consiste en que todas las agudezas están referidas a un mismo asunto (273).
} 
CATEDRAL Tomada: Revista de crítica literaria latinoamericana / Journal of Latin American Literary Criticism Deconstrucción del discurso bélico en el Poema Heroico de Hernando Domínguez.

el pintor toma en la mano izquierda, y que, descansando en el lienzo por uno de sus extremos, el cual remata en un botón de borra o una perilla redonda, le sirve para apoyar en él la mano derecha". La segunda agudeza por semejanza compara la tierra a un lienzo; en el sexto verso se introduce una tercera agudeza que compara a Ignacio cazador con el pintor del bosque, con el Apeles del monte, uno de los pintores más célebres de la antigüedad. ¿A qué obedecen estas tres metáforas pictóricas? Pues bien, la razón dada a este misterio que pone la caza en términos de pintura, reposa en el dístico de la octava que dice que la sangre dio ese color al aparato, es decir, al venablo, al arma que se utiliza, y a la verdad de semejante escena sanguinaria, se le atrevió u osó competir el retrato que deja evidencia de ese cuadro escarlata. Así, el lienzo de la tierra, por operación del cazador con su venablo, queda pintado de sangre, de la sangre de los animales del bosque, de la sangre de los animales del monte.

El primer verso de la siguiente octava hace énfasis en la negatividad del ejercicio cortesano de la caza: "El venablo vibrando cansa el bosque" (63). Entre otras cosas, "cansar" significa, según el DRAE, "quitar fertilidad a la tierra". Luego se pinta la caza de un jabalí, con la ayuda del "importuno gozque" (63). Con esto en mente, se evalúa ese oficio de adiestramiento característico de las cortes como un oficio que afecta la productividad de la tierra, ya que las aves participan activamente en la difusión de las semillas; el oficio de la caza, al restar muchos de estos animales, reduce las posibilidades de producción de plantas en los bosques, como claramente lo dibuja el poeta. Durante el adiestramiento, Ignacio también apresura un caballo hiriendo su ijar para ir tras de un corzo (mamífero rumiante), tras del cual también hay un perro cazador que lo alcanza ligeramente para entregarlo a los pies del caballo, pies por los que es hollado finalmente. Después se presenta la imagen de un garzón huyendo al haber sido “insultado del can”. Ese garzón que ha sido "muda atalaya de los peces" (64) y que ha sido comparado también a una azucena entre las flores del huerto de la laguna y a un lirio de plumas a través de un compuesto por metáforas, es perseguido en el aire por el baharí, el cual, con sus uñas de acero y su pico de 
diamante, después de haber sido desenlazado de la mano de su amo y por su velocidad, es comparado a un "rayo de pluma" que luego embiste al garzón y lo ofrece en dos mitades a su dueño. Asimismo, se muestra la imagen de su pluma salpicada con la sangre ${ }^{6}$ de su presa. (64)

Luego se presenta la imagen del ascálafo contra cuyos dos ojos comparados a "dos carbunclos [...] se conspira/ la turba de cuervas que a la noche iguala" (64); el ascálafo es, o bien movido por la envidia, o bien precipitado por la ira hacia todas ellas, hacia esas cuervas que están acicalándose con la ayuda de sus picos y que son semejantes a las mayores mariposas de la noche. (64) Posteriormente se presenta el cuadro de toda la turba derramada al viento "en pavoroso súbito gemido" (65) y en obediencia a un presagio, una sombra o un latido, las cuervas se dispersan, pero el sacre, como un "Euro ${ }^{7}$ de pluma", se desata de nube en nube para ser el escollo de la turba. (65) A la caza se une un "halcón ayuno/ (auxilio al sacre)" escalando las nubes hasta que ambos aprisionan a las cuervas, el uno arriba y el otro abajo: "[...] y así el uno/ nadir, cenit el otro fue plumado" (65). Con respecto a estos dos depredadores, dicen las cuatro octavas finales: "Scila en aqueste dio, cuando importuno/ Caribdis en el otro escapó alado:/ náufrago así el esquife se reparte,/ y cada escollo vinculó su parte” (65). Los versos anotados muestran a estas aves de cetrería como encarnaciones de Caribdis (que ya se tuvo la oportunidad de explicar) y Escila, otra mujer convertida en monstruo marino y cuyo cuerpo, en su parte inferior, estaba rodeado de seis perros, devoradores de todo aquello que pasaba cerca de ellos (Grimal 173). Dice Grimal que estos dos monstruos estaban ubicados en el mismo estrecho de Mesina, uno opuesto al otro, a la distancia de un tiro de arco (87), de manera que para los navegantes era difícil escapar de alguno de ellos. Las aves cazadoras empleadas en el oficio cortesano de cetrería son de ese modo

${ }^{6}$ Para aludir a la sangre con que quedan salpicadas las plumas del baharí, el poeta acude a un juego metafórico (coral-rojo). Así pues, "coral" remite metafóricamente al color de la sangre del garzón, del ave prendida.

${ }_{7}^{7}$ Viento del sudoeste, hijo de Eos (la Aurora) y de Astreo (Grimal 188). 
CATEDRAL Tomada: Revista de crítica literaria latinoamericana / Journal of Latin American Literary Criticism Deconstrucción del discurso bélico en el Poema Heroico de Hernando Domínguez.

comparadas a monstruos devoradores que se reparten el esquife, la embarcación náufraga apresada.

Durante la descripción de su adiestramiento, Ignacio es comparado con Colón, con lo que el poeta aprovecha de nuevo la ocasión para aguzar su crítica en contra de la guerra: "Colón de Marte, investigó en su acero/ en carta de matar líneas mayores". Según Meo Zilio la expresión “carta de matar", teniendo en cuenta que ha llamado a Ignacio "Colón de Marte" en el verso anterior, "parece tratarse de un juego de palabras relacionado con "carta de marear", 'mapa en que se describe el mar, o una porción de él, con sus costas o parajes donde hay escollos o bajíos' (Dicc. Acad.)" (Domínguez 104). Con la referencia a Colón y el juego paronomástico de palabras inferido por el crítico italiano, no resulta extraño entonces que se vincule la guerra con el Descubrimiento. Más adelante, en esa misma octava, se califica al acero o espada como "ángulo crudo o paralelo fiero" (66); allí el poeta califica a la espada (juego metafórico: ángulo, paralelo) como “crudo" y "fiero" aludiendo así a la ferocidad del arma y después introduce una lamentación que relaciona la guerra con el arte y la naturaleza: “¡Oh del hombre occidente, y cuán severo/ error te impele a doctrinar horrores,/ pues a rendir tu flaco balüarte/ naturaleza se conjura y arte!” (66). Introduce otra referencia al occidente y relaciona ese occidente con el hombre cuyo error lo empuja a doctrinar horrores, a través de una agudeza por paronomasia (errores y horrores) que se despliega del plano fonológico al semántico para aludir al error de la ambición del hombre que lo lleva a adoctrinar o enseñar horrores; aquí se puede pensar en el adoctrinamiento de occidente, en los pueblos nativos americanos catequizados en la cultura, lengua y religión españolas; luego relaciona la guerra con el conocimiento y la naturaleza en el dístico de la octava, arriba citado. Dice que naturaleza y arte se conjuran para rendir el flaco baluarte de ese hombre ambicioso. Así naturaleza y $\operatorname{arte}^{8}$ se unen para servir como el baluarte o protección del hombre de armas. La técnica y las materias primas sacadas de la

${ }^{8}$ Del latín ars, artis que según el diccionario Vox significa "habilidad, talento [...], profesión, técnica $[\ldots] "$ " (42). 
naturaleza serán puestas al servicio de una guerra de adoctrinamiento impuesta con la feroz espada.

Nótese, entonces, la negatividad con que es trazado el ejercicio de caza de animales. Este oficio, propio del ambiente cortesano, y del que Ignacio no converso aún ha participado, es evaluado como un ejercicio sanguinario. El poeta muestra imágenes antitéticas de los animales que van a ser cazados: el hermoso garzón vigilante del mar, comparado a una azucena y después partido en dos mitades (imagen barroca de violencia), también la turba de cuervas, comparadas a hermosas mariposas de la noche, las cuales vienen a constituirse después en un espectáculo de horror y confusión al ver a sus cazadores tras de sí. Todo este oficio es el que viene a pintar de sangre el bosque europeo. Aquí, el poeta utiliza un cuadro pictórico, pero esta vez lo pinta con color escarlata, lo pinta con la sangre de los animales del bosque. Con todo lo anterior, la operación de caza, viene a simbolizar en menor escala la violencia promovida desde los ambientes cercanos al ámbito del poder, violencia que siempre estará evaluada de manera negativa por Domínguez y que está muy vinculada con los ejercicios de Conquista y adoctrinamiento.

Lo bélico, relacionado con la Conquista, se verá con negatividad en el Poema... de manera muy frecuente, sobre todo en lo referido a sus implicaciones sobre el medio silvestre europeo. En el canto primero del libro tercero, se narra que después de haber sido recibido con humilde hospitalidad por Isabela Rosel, Ignacio elige, para pasar a Italia, una embarcación carcomida por moluscos. En ese punto, y saliéndose de las anécdotas ignacianas, el poeta aprovecha la ocasión para dirigirse a diferentes cosas tangibles e intangibles y relacionadas con la guerra, por medio de apóstrofes ${ }^{9}$. El yo lírico inicia con una agudeza por ponderación misteriosa en el primer apóstrofe, dirigido al mar; la octava XXVIII, dice: “¡Oh mar, oh tú, devorador crüento” (180) y la razón del calificativo “del bien nacido leño en la montaña" (180). Sigue con la referencia al Noto, "dios del

9 "Figura retórica que consiste en dirigir la palabra en tono emocionado a una persona o cosa personificada" (Marchese y Forradellas 33). 
CATEDRAL Tomada: Revista de crítica literaria latinoamericana / Journal of Latin American Literary Criticism Deconstrucción del discurso bélico en el Poema Heroico de Hernando Domínguez.

viento Sur, cálido y cargado de humedad" (Grimal 383) cuyo soplo mofador violento escarnece la saña del Ábrego, "viento templado y húmedo del sudoeste, que trae las lluvias" (DRAE en línea); el mar, enfurecido por éste, roe con su elemento las tablas del "cadáver de velero pino", conducido a su ruina. (Domínguez 180) Los semas "cadáver" y "rüina" denotan destrucción, apuntalando así a la muerte de las materias primas forestales europeas con las cuales se fabrican las embarcaciones.

En la siguiente octava (XXIX), el poeta, a la manera gongorina, retrotrae la historia legendaria del mar introduciendo la figura mitológica de Tifis, el primer piloto del barco Argo, a quien se le atribuía ser muy buen conocedor de los vientos y del curso de los astros, entre otras cosas (Grimal 515-516). El poeta se dirige a él: “¡Oh Tifis, tú conculcador primero,/ en bastarda, en plebeya, en torpe haya,/ del no violado imperio del mar fiero,/ de la hasta ti temida, undosa raya!" (180)

El mar, entonces, con su furia, quebranta las naves fabricadas por el hombre con las materias naturales engendradas por la tierra y con las cuales se ha atrevido a desafiarlo. Aquí el poeta utiliza la figura retórica de la metonimia (la parte enuncia al todo); así, la "deshecha quilla" y la "quebrantada entena" dibujan para el lector una embarcación herida por el mar.

Ahora el poeta se dirige a un antivalor: "¡Oh interés, que las selvas arrojaste/ en tanto unido monstruo, en tanto abeto,/ en el piélago undoso en quien hallaste/ en tantos siglos mundo a ti secreto; [...]/ en cuyo alcance, quebrantadas quillas,/ más que ellas conchas, diste a las orillas!" (180). Semejante osadía de lanzar selvas enteras al furioso e indomable lecho marino dará a luz el no pronosticado hallazgo de un mundo que durante mucho tiempo estuvo oculto para el hombre europeo y, aunque casi deshechas, las quillas logran arribar a las orillas hasta entonces desconocidas.

A continuación, el poeta se dirige al escollo con que se encuentra el navegante a su paso: “¡Oh escollo, tú, del norte hidropesía,/ Clicie de piedra que sus rayos bebes,/ [...] alados bosques y montañas leves/ del ponto falso, y a 
inquirirle al día/ los más secretos términos, atreves/ tanto pueblo de naos, que sin camino/ las zonas borra con precito lino!" (180). Los escollos o islotes rocosos serán como imanes que atraigan a los temerarios navegantes quienes se aventuran a lanzar sus "alados bosques". Por su ambición, el hombre se fía del ponto falso, del mar falso, que en un momento se le presenta calmado, pero luego se enfurece. Aun así, el navegante europeo manda su pueblo de naos errantes, sin camino, pues aún no saben la sorpresa que se encontrarán.

Sigue el apóstrofe: "Tú, pues, codicia, pérfido piloto, $[\ldots]$ con tres quillas rompiste el nunca roto/ piélago occidental de otras algunas;/ y sobornando al mar náutico voto,/ porfiaste hasta las rocas importunas/ del Istmo, que cordel son diamantino" (181). A través de estos versos, el poeta se dirige a la codicia como el impulso, el piloto que conduce las embarcaciones. El sintagma "tres quillas", que rompen el hasta ahora nunca roto piélago occidental, remite metonímicamente a las tres carabelas que primero arribaron al continente americano, a saber, Pinta, Niña y Santa María. La codicia española, motor de la empresa bélica que se llevará a cabo en las tierras antes desconocidas, empieza su pelea con los obstáculos naturales, luchando tercamente incluso contra las rocas importunas del célebre Istmo panameño (denominación actual).

Sigue el apóstrofe a la codicia: "A pesar, pues, del indio, cuya frente,/ cuya espalda vistió exquisita suma,/ de plumas ésta, aquélla del luciente/ aljófar que le dio su rica espuma:/ la flecha a quien sus aves dieron pluma,/ quebrada, violó perlas en la orilla/de esta mi cuna tu obstinada quilla" (181).

La codicia española rompe el piélago nunca alcanzado, aun a pesar del indio, de quien el poeta pasa a hacer una representación pictórica: su sencilla indumentaria de plumas y de aljófar (perla de no gran valor); también sus armas, la flecha y la jara, no con el mismo poder arrasador que las del europeo, como demostraré enseguida. Nótese que la voz poemática presenta al indígena como el dueño legítimo de esa indumentaria que le da su propio entorno natural, a través de las expresiones "el aljófar que le dio su rica espuma" y "la flecha a quien sus aves dieron pluma"; en la primera expresión se personifica a la espuma, quien 
CATEDRAL Tomada: Revista de crítica literaria latinoamericana / Journal of Latin American Literary Criticism Deconstrucción del discurso bélico en el Poema Heroico de Hernando Domínguez.

ofrece sus haberes al indígena; en la segunda, el sujeto a quien se atribuye la posesión de las aves no es otro que el mismo indígena a quien esas aves, por su parte, dan su pluma. Después, el yo lírico y empírico, en carácter de criollo, demuestra su pertenencia al terruño indígena y se pone del lado del habitante nativo de ese terruño a través del sintagma posesivo "mi cuna", manifestando un tono de distanciamiento y de diferenciación con el europeo, con el español que ha osado violar las espumas marinas.

La octava XXXIV sigue con la idea de la instrumentalización de la naturaleza al servicio de una empresa bélica: "Desatada, después, sierpe de pino,/ rompió con alas de obstinada lona/ en nunca hollados piélagos camino", la XXXV dice: "Condujiste después linos segundos/al mar, [...] en los senos esconde más profundos/ lo que en las conchas más rugosas llora;/ muró en vano, después, sus nuevos mundos,/ de mástiles rompidos en sus peñas” (181).

Esta octava dibuja una codicia que conduce nuevas embarcaciones (linos ${ }^{10}$ segundos) a los nuevos mundos. El mar, dehesa natural y sus monstruos, muran o protegen en vano sus mundos; las embarcaciones conducidas por la codicia, aunque heridas por las peñas marinas, obstinadamente arriban a esos nuevos territorios.

La octava XXXVIII, termina: “¡Oh, cuánto cuesta al lusitano noble,/ a las Quinas del viento triunfantes/ (que en cuanto ladra hipérboles de roble,/ y de obstinado pino arma elefantes/ piélago no hay fragoso que no doble),/ hallar el firmamento de diamantes,/ la láctea vía de la perla neta,/ y del rubí la eclíptica

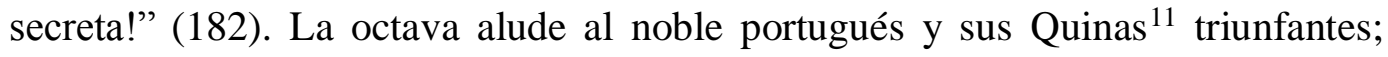
este imperio europeo "ladra hipérboles de roble", agudeza por exageración (hipérbole, valga la redundancia) para dar una visión al lector de la cantidad de embarcaciones que llegan de allá a América. Cuando dice "de obstinado pino arma elefantes" se refiere a las grandes embarcaciones fabricadas con madera, que

\footnotetext{
${ }^{10}$ La definición poética de "lino" dada por el DRAE en línea, es "vela de la nave”. Aquí también se trata de una metonimia.

11 "Quina" son las "armas de Portugal, que son cinco escudos azules puestos en cruz, y en cada escudo cinco dineros en aspa" (DRAE).
} 
obstinadamente buscan llegar a los nuevos territorios. Se puede advertir aquí una agudeza por ponderación misteriosa, cuya primera parte, vale decir, el misterio, reposa en los primeros cinco versos y la razón dada al misterio, la razón de tal empresa costosa que arroja al mar selvas de embarcaciones, está dada en los tres últimos versos: hallar grandes cantidades de minerales preciosos, hecho que se deduce cuando se mira que el poeta sugiere, a través de dos agudezas por semejanza (metáforas celestes), la gran cantidad de piedras preciosas en pos de las cuales vienen los europeos: "firmamento de diamantes" y "vía láctea de la perla neta" (182. Pongo en cursivas las semejanzas en cuestión).

En las octavas analizadas, asimismo, se puede trazar una isotopía ${ }^{12}$ relativa a las materias primas forestales, conformada por los siguientes términos: "leño", "montaña(s)", "tablas", "pino", "haya", "selvas", "abeto", "bosques", "roble". Con la instrumentalización de estas materias primas (madera), a través del desarrollo de la técnica, se llevará a cabo la expoliadora empresa de la Conquista. Entonces, cuando el vate santafereño pone ante los ojos de su receptor selvas arrojadas al mar, en lugar de embarcaciones, a través del uso de metonimias (el material por la cosa), el lector puede advertir un tratamiento retórico del material verbal que se despliega del significante al plano del significado y que la intención del poeta es hacerle ver la gran cantidad de materias primas silvestres puestas al servicio de dicha empresa bélica. Pero esa empresa bélica tendrá una dimensión transatlántica en lo que al desgaste de recursos naturales se refiere; por un lado, se despejarán los bosques europeos (vegetales) para, por otro lado, allende el mar, llevar a cabo la apropiación de grandes cantidades de metales preciosos americanos (minerales).

Con esto se empieza a presentar una deconstrucción de la tan afamada Conquista, exaltada en otros poemas épicos españoles y coloniales, mostrando el autor su particularidad con imágenes vívidas de saqueo de los productos europeos y americanos. La empresa bélica, casual y lograda por la fortuna, obedece al

\footnotetext{
${ }^{12} \mathrm{La}$ isotopía es un esquema de interpretación en el nivel semántico, es el nivel de coherencia interpretativa dado por la recurrencia de ciertos términos (Eco 131).
} 
CATEDRAL TOMADA: Revista de crítica literaria latinoamericana / Journal of Latin American Literary Criticism Deconstrucción del discurso bélico en el Poema Heroico de Hernando Domínguez.

interés y a la codicia. Así, la propuesta retórica del poeta se pone al servicio de una evaluación negativa de tal empresa que califica como codiciosa ${ }^{13}$. La llegada al suelo americano de los conquistadores europeos, entonces, no es puesta como hazaña en este caso, sino como obstinación que viola la naturaleza propia, desafía el inmenso poderío marino arriesgando vidas humanas, saquea la naturaleza ajena y quita lo que por derecho pertenece al nativo del suelo, al indígena y lo que ahora por derecho, por haber nacido allí, cree el criollo que también le pertenece.

Otro caso de instrumentalización de la naturaleza puesta al servicio de la guerra se aprovecha cuando Ignacio y sus discípulos hacen voto al Papa en Roma para que los autorice ir a Jerusalén. Sin embargo, al tratar de embarcarse con rumbo a Tierra Santa se encuentran con que el mar de Venecia está atestado de naves bélicas, pues Italia y España se han aliado en la resistencia contra la invasión turca. Nuevamente las imágenes forestales invaden el lecho marítimo: "Todo el bosque echó al agua [...] la veneciana/ pompa naval, que a repetido pino/ ancho nido mulló su espuma cana” (Domínguez 333). Más adelante, la octava LXVIII, dice: "Montañas, pues de islas fluctuantes,/ ciegos montes de mástiles calados [...] a la Ignacio ilustre Compañía/ el paso del Jordán les impedía” (333). Así, se muestra la imagen, de nuevo metonímica, de las montañas que visitan el mar, dando la visión de un hábitat completo de boca al mar. A continuación, la naturaleza pasa a introducirse como sujeto militar: la "armada encina, las "fieras de alado pino" (333). De nuevo, las metonimias enfatizan la desmedida instrumentalización de los recursos forestales para una empresa bélica, ninguno de cuyos contrincantes es exaltado; ambos son puestos como sujetos de tecnificación para la guerra, como claramente lo dibujan las siguientes octavas: "al turco Solimán, que fatigada,/ o de veleros bosques impedida, toda el agua oprimía” y en el caso italiano: "Todo el bosque echó al agua, y todo el lino/ al aire

\footnotetext{
${ }^{13}$ Este pasaje está tomado de un fragmento de las Soledades: por boca de un anciano pescador se pone en tela de juicio la empresa de la Conquista (Góngora 248-250), incluso algunas metonimias están sacadas de esa obra; sin embargo, en el poema del neogranadino, a diferencia de la obra del cordobés, aquí sí se puede trazar una isotopía que permite dibujar el juicio negativo y la visión trágica del saqueo de materias primas europeas; además, la diferenciación con el español y su sentido de pertenencia con el terruño americano son muy particulares en Domínguez.
} 
convistió, la veneciana pompa naval,/ que a repetido pino/ ancho mulló su espuma cana" (333). Se reitera, lo importante aquí no es el valor guerrero, sino el gasto desmedido de la madera como materia prima en la fabricación de las embarcaciones que se destinarán a la guerra, tal como lo dibuja claramente el poeta.

Las imágenes anteriormente estudiadas, en diálogo con la estética gongorina, se salen casi que por completo de la fábula de la historia hagiográfica para mostrar una concepción decepcionada de las empresas bélicas debido a lo que comportan para el medio silvestre, para el mismo conquistador que se avienta a tales riesgos, para los productos nacidos en América, para las materias primas del suelo europeo. Lo importante aquí parece ser dibujar, de manera vívida, la devastación del medio natural, ora bien europeo, ora bien americano.

Se ha visto cómo Hernando Domínguez Camargo deconstruye el discurso exaltador de las empresas bélicas demostrando, por medio del uso de metonimias, e isotopías referidas al medio silvestre, lo que la instrumentalización excesiva de las materias primas forestales implica para el medio natural. Sin embargo, este no es el único recurso utilizado por el poeta en su juicio contra el discurso bélico; las invectivas o sátiras son muy comunes en el Poema ... y algunas de ellas le apuntan a la guerra.

A través de la derrota de Ignacio y sus soldados en Pamplona (Canto Tercero del Libro Primero), se da la visión de una ciudad española hecha escombros, después de haberse mostrado altiva en un principio por su aparente carácter inexpugnable, el río que la bordea, sus murallas y sus cañones que ladran fuego. El cañón y la pólvora, invenciones no muy antiguas y cuyo poder arrasador se ha ido desarrollando con el paso de los siglos, reciben una aguda crítica en el Poema ...: “¡Oh pólvora, invención del áspid humano! [...] qué enemigo a la vida fatal, labró tu mano" (72), recalcando así las manos que lo han fabricado como enemigas de la vida humana. Sigue la invectiva: "La centellosa sangre has penetrado/ del pedernal en las heridas venas,/ y de sal y alquitranes fabricado/ infierno breve en rápidas arenas [...] que en breve instante comes apresurado,/ lo 
CATEDRAL TOMADA: Revista de crítica literaria latinoamericana / Journal of Latin American Literary Criticism Deconstrucción del discurso bélico en el Poema Heroico de Hernando Domínguez.

que no pudo un siglo desganado" (72). Así, a través de esta crítica, cuyo modelo es Ariosto, el poeta muestra la potencia arrasadora del invento y cómo la guerra es ahora más cruenta, pues el desarrollo del poder devorador de vidas de esas armas hace que en un instante breve acaben lo que no pudo todo un siglo de enfrentamientos (disonancia).

Sin embargo y a pesar de que la guerra se ha hecho cada vez más sanguinaria con el correr de la historia, el valor heroico del guerrero es desplazado por la técnica al servicio de la guerra, como lo demuestra Domínguez en la octava CXXX: “Antes que tú nacieses, el membrudo/ jayán era temido, y el soldado/ la defensa preciaba de su escudo;/ un dardo de la cuerda era arrojado/ al áspid más fatal; ariete rudo/ desmigajaba el muro levantado;/ nacida tú al cañón, halló tu ira/ contra distantes vidas longemira" (73).

Antes del desarrollo moderno de la técnica militar, el hombre era el protagonista en enfrentamientos cuerpo a cuerpo y sus armas eran su valentía, una valentía casi mítica, también su fuerza, su complexión gigantesca (el gigante pretérito era temido); su defensa, su escudo y el ariete, arma utilizada para derribar los muros protectores del enemigo. Después, con el avance de la técnica militar, el hombre, como figura heroica, empieza a perder protagonismo, mientras la fabricación de sus armas arrasa mayor número de vidas. Es por eso que el poeta no se dirige al hombre, sino al instrumento de guerra fabricado por él, a través de la personificación de la pólvora como su interlocutor (apóstrofe); de ese modo, la voz poética desdice de la virtud heroica del guerrero moderno, quien ya dista mucho de ser el guerrero héroe protagonista de antes: ahora las protagonistas vienen a ser las armas.

En este punto no sobra enfatizar en una octava que pertenece al mismo canto al que se está haciendo referencia en este momento. Cuando Ignacio, en la batalla contra los franceses, advierte en sus compañeros una actitud derrotista que los empuja a la huida, profiere una exhortación militar denodada de luchar hasta la misma muerte. Válgase la aclaración de que el poeta no desea exaltar la valentía española que está siendo vencida, ni la francesa vencedora, sino la 
exhortación ignaciana que se despliega a lo largo de doce octavas; en este momento el poeta hace uso de recursos ya largamente trabajados en la tradición épica, como lo son las exhortaciones militares; en Ercilla, por ejemplo, se presenta este tipo de discursos tanto en un bando como en el otro (Caupolicán, por ejemplo); Domínguez Camargo hace gala de su conocimiento del discurso épico militar y lo introduce en la voz de Ignacio. Entre las expresiones de ánimo y valentía proferidas por el Santo, se resaltan las siguientes: "Huyendo, sólo le franqueáis más gloria/ que os diera, muerto él, vuestra victoria" (75); "advertid que en certamen tan acedo,/ el mayor enemigo es vuestro miedo", "haced siquiera que merezca el saco", "pelear sin esperanzas es victoria:/ sin gloria muere el que murió en la cama” (76); “¿Veis aquel escuadrón tan apiñado?/ ¿veis la selva de lanzas enemiga?/ solo un grano será cada soldado" (77); "Si del galo Sansón culta melena/ enervare al león, alta sea gloria/ fabricar nuestra pira en su colmena,/ que dulce nos conserve la memoria" (78).

Estas exhortaciones, de tono más renacentista que barroco, al no ser su comprensión tan complicada y al prescindir casi que por completo del asunto mitológico (Meo-Zilio 88), animan a los soldados españoles; sin embargo, lo interesante aquí viene a ser la comparación utilizada por el poeta para sugerir el resultado de la exhortación ignaciana en el ánimo y las acciones del bando español: "Tigre crïollo es ya, quien fue medrosa liebre" (79). La agudeza por semejanza que relaciona el valor español con un tigre criollo puede referirse a dos cosas: primero, puede ser una metáfora zoológica que relaciona la fiereza del animal americano con la valentía española después de haber escuchado la exhortación ignaciana; aquí el sustantivo es "tigre" y el adjetivo "criollo"; segundo, puede semejar el valor español al criollo que pelea como tigre; aquí el sustantivo es "criollo" y el adjetivo, "tigre". Aunque los criollos no empezaron a planear su lucha de independencia sino hasta fines del siglo XVIII, la lucha del criollo por afirmarse como tal y diferenciarse del español, se empezó a dar desde el siglo XVI, no por las armas, claro está, pero sí por mediación de la palabra; por lo tanto, la expresión "tigre criollo" podría aludir a la lucha discursiva del criollo 
CATEDRAL Tomada: Revista de crítica literaria latinoamericana / Journal of Latin American Literary Criticism Deconstrucción del discurso bélico en el Poema Heroico de Hernando Domínguez.

americano contra el español; yendo un poco más allá, se podría tomar como una expresión profética de la lucha futura de independencia en las etapas protonacionales; es por eso que para el poeta la metáfora adecuada para mostrar el valor recobrado por el bando español, es, precisamente, la fiereza criolla.

Abriendo un paréntesis histórico para corroborar lo anterior, Mazzotti afirma que la designación "criollo" empezó a ser usada desde 1567, siendo aplicada a los neo-europeos; originalmente adquirió una intención insultante, pues primariamente el término era aplicado a los hijos de africanos nacidos en la Nuevas Indias Occidentales. Pero después la categoría de criollo empezó a adquirir una nueva connotación que remitía a un fundamento social y legal más que biológico. Asimismo, empezó a remitir a un sentimiento de pertenencia a la tierra. Además, los criollos de los siglos XVI y XVII tuvieron que hacer elaboraciones intelectuales de diverso orden para contestar a los insultos con que eran menospreciados por su situación de nacidos en América. A continuación, se parafrasea a Suárez de Figueroa, citado por Mazzotti: para Suárez era aborrecible el mismo nombre del mundo descubierto, "Indias". Seguidamente contrapone el mundo peninsular al nuevo. A tal grado llega su desprecio, que llama "sabandijas" a quienes se crían en los límites antárticos y occidentales. Como es de suponerse, las respuestas a tales críticas e insultos no se dieron a esperar; los criollos y criollistas, a través de numerosas páginas, buscaron una exaltación de los hijos de los conquistadores nacidos en América, por medio de otorgarles una forma diferenciadora de identidad hispana que ya no era la peninsular, sin cabida alguna al esbozo de un ideario de independencia, tampoco de igualdad con los indígenas y mestizos. Entre las múltiples contestaciones se resaltan las siguientes, las cuales, claro está, son diferentes maneras de exaltar el carácter criollo: la Grandeza mexicana (1604) de Bernardo de Balbuena, los Problemas y secretos maravillosos de las Indias de Juan de Cárdenas (1591); en el Perú, Buenaventura de Salinas y en 1620 Francisco Fernández de Córdoba con Calancha. La primera de estas obras, y con ella el Paraíso occidental de Sigüenza y la Fundación y grandezas de Limas de Rodrigo de Valdés, constituyen una literatura exaltadora 
de las ciudades o riquezas físicas y territoriales, hecho que revela un locus de enunciación diferente del español peninsular (Mazzotti 11-14).

\section{Conclusión}

En este artículo se ha pretendido llamar la atención sobre la deconstrucción del discurso bélico sescentista efectuada por el poeta neogranadino Hernando Domínguez Camargo, haciendo énfasis especial en la propuesta particular del autor, vale decir, aquellos episodios que se salen de la fábula hagiográfica y que demuestran a las claras el deseo del yo poemático de introducir un juicio muy propio del discurso militar en un tiempo particular y en unos contextos específicos (América y Europa); recuérdese que el poeta ha evaluado negativamente la guerra por varias razones: en primer lugar, por aquello que ha comportado para el medio silvestre europeo, cuyas materias primas forestales han sido arrojadas al mar para llevar a cabo guerras entre naciones europeas (España, Italia y Turquía), pero también para llevar a cabo la empresa transatlántica de Conquista y la consecuente expropiación de los productos americanos; y son esos minerales preciosos americanos, precisamente, con los cuales se enriquecerá no solo el hombre europeo, sino también con los cuales se adornarán las lujosas ciudades europeas. También, para el poeta ese heroísmo militar del hombre que se ha venido exaltando desde tiempos antiguos, en el momento de la composición del Poema... ya no funciona, puesto que, debido al desarrollo técnico de las armas de destrucción masiva, como los cañones y la pólvora, cualidades como la valentía, la fuerza y el honor militar, han sido relegados a un plano de segundo orden. Sumado a todo ello, el poeta ha aprovechado esta concepción de la Conquista para introducir su visión de criollo y legitimarse como dueño del suelo americano en el que ha nacido, legitimarse en el derecho que como tal tiene sobre los productos que están siendo saqueados por el 
CATEDRAL TOMADA: Revista de crítica literaria latinoamericana / Journal of Latin American Literary Criticism Deconstrucción del discurso bélico en el Poema Heroico de Hernando Domínguez.

español y legitimar la lucha de la clase criolla que se ha empezado a dar en ese momento, no desde las armas, pero sí desde las letras.

\section{Bibliografía}

Brioschi, Franco y Constanzo di Girolamo. Introducción al estudio de la literatura. Trad. Carlos Vaíllo. Barcelona: Editorial Ariel, 1988. Impreso.

Covarrubias, Sebastián. Tesoro de la lengua castellana y española. Barcelona: Editorial Alta Fulla, 1987. Impreso.

Cros, Edmond. Literatura, ideología y sociedad. Trad. Soledad García Mouton. Madrid: Editorial Gredos, 1986. Impreso.

Diego, Gerardo. Antología poética en honor de Góngora, recogida por Gerardo Diego. Desde Lope de Vega a Rubén Darío. Madrid: Alianza Editorial, 1927. Impreso.

Diccionario de la lengua española - Vigésima segunda edición http://buscon.rae.es/draeI/SrvltConsulta? Recuperado el 3 de octubre de 2011.

Diccionario Latino-Español. Español-Latino Vox. Barcelona: Biblograf S.A., 1999. Impreso.

Domínguez, Hernando. Obras. Caracas: Biblioteca Ayacucho, 1986. Impreso. Eco, Umberto. Lector in fabula: Cooperación interpretativa en el texto narrativo. Trad. Ricardo Pochtar. Barcelona: Editorial Lumen, 1999. Impreso. Evia, Xacinto de. Ramillete de varias flores poeticas, recogidas y cultiuadas en los primeros abriles de sus años [Texto impreso] / por el maestro Xacinto de Euia ... Madrid: Imprenta de Nicolás de Xamares, mercader de libros, 
1675.

http://bibliotecadigitalhispanica.bne.es/view/action/singleViewer.do?dvs= 1313692223548 362\&locale=es_ES\&VIEWER_URL=/view/action/singl eViewer.do?\&DELIVERY_RULE_ID=10\&frame. Recuperado el 18 de agosto de 2011.

Góngora y Argote, Luis de. Poesías. México: Editorial Porrúa, S.A., 1993. Impreso.

Gracián, Baltasar. Agudeza y arte de ingenio. Madrid: Espasa-Calpe, S.A., 1974. Impreso.

Grimal, Pierre. Diccionario de mitología griega y romana. Trad. Pedro Pericay. Barcelona: Ediciones Paidós Ibérica S.A., 2008. Impreso.

Hampe Martínez, Teodoro. et al. La tradición clásica en el Perú virreinal. Fondo Editorial Universidad Nacional Mayor de San Marcos. Lima, 1999. Impreso.

Marchese, Angelo y Joaquín Forradellas. Diccionario de retórica, crítica y terminología literaria. Trad. Joaquín Forradellas. Barcelona: Editorial Ariel, 2007. Impreso.

Mazzotti, José. Agencias criollas. La ambigüedad en las letras hispanoamericanas. Pittsburg: Biblioteca de América, 2000. Impreso. Meo-zilio, Giovanni. Estudio sobre Hernando Domínguez Camargo y su S. Ignacio de Loyola. Poema heroyco. Messina: Casa Editrice G. D’anna, 1967. Impreso.

Segre, Cesare. Principios de análisis del texto literario. Trad. María Pardo. Barcelona: Editorial crítica, 1985. Impreso.

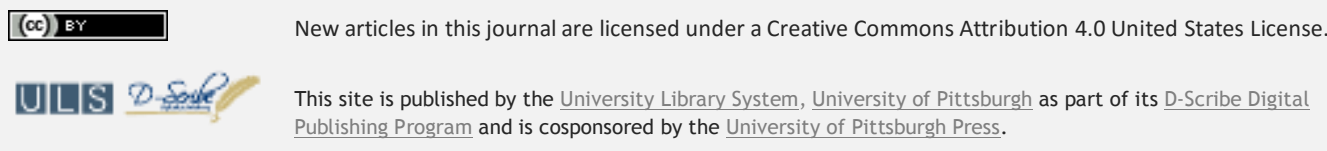

